\title{
Life-history traits and potential invasiveness of introduced pumpkinseed Lepomis gibbosus populations in northwestern Europe
}

\author{
Julien Cucherousset • Gordon H. Copp • \\ Michael G. Fox · Erik Sterud · Hein H. van Kleef • \\ Hugo Verreycken · Eva Záhorská
}

Received: 1 February 2008/Accepted: 12 August 2008/Published online: 30 June 2009

(C) The Author(s) 2009. This article is published with open access at Springerlink.com

\begin{abstract}
To evaluate the potential invasiveness of pumpkinseed Lepomis gibbosus introduced to northwestern European inland waters, growth and reproduction traits were examined in ten populations along a trajectory spanning northwestern Europe (Norway, England, Holland, Belgium and France) and evaluated
\end{abstract}

J. Cucherousset

Salmon \& Fisheries Team, Centre for Environment, Fisheries \& Aquaculture Science, Lowestoft, Pakefield Road, Lowestoft, Suffolk NR33 OHT, UK

J. Cucherousset

EcoLab Laboratoire d'Écologie Fonctionnelle, UMR 5245 (CNRS-UPS-INPT), Université Paul Sabatier, Bât. 4R3,

118, route de Narbonne, 31062 Toulouse, Cedex 9, France

Present Address:

J. Cucherousset

School of Conservation Sciences, Bournemouth

University, Poole, Dorset, UK

\section{G. H. Copp ( ()}

Salmon \& Freshwater Team, Centre for Environment, Fisheries \& Aquaculture Science, Lowestoft, Pakefield Road, Lowestoft, Suffolk NR33 OHT, UK

e-mail: gordon.copp@cefas.co.uk

\section{G. H. Copp}

School of Conservation Sciences, Bournemouth

University, Poole, Dorset, UK

\section{G. Fox}

Environmental and Resource Studies Program and Department of Biology, Trent University, Peterborough, ON K9J 7B8, Canada in light of published dataset from Europe. In the 848 pumpkinseed captured, maximum age was 3-4 years, with a sex ratio near unity in all but one population. Significant variations with increasing latitude were observed in adult growth (age 2-3 increment in total length, TL) and mean age at maturity $\left(A_{\mathrm{M}}\right)$, with

E. Sterud

National Veterinary Institute, P.O. Box 8156 Dep., 0033

Oslo, Norway

Present Address:

E. Sterud

National Institute of Technology, St. Hanshaugen,

Akersveien 24 C, P.O. Box 2608, 0131 Oslo, Norway

H. H. van Kleef

Bargerveen Foundation, Department of Animal Ecology

and Ecophysiology, Department of Environmental

Science, Radboud University, Heyendaalseweg 135, 6525

AJ Nijmegen, The Netherlands

H. Verreycken

Research Institute for Nature and Forest, Duboislaan 14, B-1560 Groenendaal-Hoeilaart, Belgium

E. Záhorská

Faculty of Natural Sciences, Department of Ecology,

Comenius University, Mlynská dolina B2, 84215

Bratislava, Slovakia 
non-significant variations observed in juvenile growth (TL at age 2), sex ratio and gonado-somatic index. As observed elsewhere in Europe, mean $A_{\mathrm{M}}$ decreased significantly with increasing TL at age 2 . Using this relationship, which has been proposed elsewhere as a potential predictive model of pumpkinseed invasiveness, eight of the ten populations could be provisionally categorized as 'non-invasive' (five populations), 'transitional' (one population) and 'potentially invasive' (two populations), with two populations not categorized due to insufficient data. Based on the available knowledge on each population, the relationship between juvenile growth and age at maturity appeared to predict reasonably the status of pumpkinseed in northwestern Europe and its applicability to other species should be tested.

Keywords Reproduction - Body condition . Life-history strategy $\cdot$ Latitudinal clines .

Non-native species $\cdot$ Centrarchidae

\section{Introduction}

An invasive fish species has been defined as an "indigenous or nonindigenous species that spreads, with or without the aid of humans, in natural or seminatural habitats, producing a significant change in composition, structure, or ecosystem processes, or cause severe economic losses to human activities" (Copp et al. 2005). Invasive fishes are of increasing concern to the biodiversity and ecosystem integrity of fresh waters (e.g. Vitousek et al. 1997; GarcíaBerthou et al. 2005), and tools to predict species invasiveness are needed (Kolar and Lodge 2001). Life-history traits have been shown to be particularly good predictors of non-native fish establishment success in many cases (e.g. Fausch et al. 2001; Marchetti et al. 2004; Vila-Gispert et al. 2005; Olden et al. 2006), and life-history perspectives are useful for a mechanistic-based understanding of the patterns of fish invasions and species invasiveness (Olden et al. 2006; Ribeiro et al. 2008). Intra-specific variation in life-history traits at large spatial scales (i.e. latitudinal clines) have also been demonstrated, due to the relationship between latitude and temperature. For instance, the decrease in growth and the increase in age at maturity with latitude has been observed in many fish species (Blanck and Lamouroux 2007 and references therein). Because these traits influence species potential invasiveness, latitudinal changes in the invasiveness between populations of a non-native species can be expected across its introduction range. Consequently, more integrative approaches of life-history traits of non-native species along latitudinal clines are needed to assess their potential invasiveness (García-Berthou 2007). Indeed, studies on life-history traits of non-native species usually consider only a limited latitudinal gradient, without the most northerly or southerly populations (e.g. Copp and Fox 2007; Fox et al. 2007; Ribeiro et al. 2008).

Recent applications in the biology of invasive fishes are now addressing the adaptations in lifehistory traits of non-native fishes in their new environments, in particular the introduction of North American fish species (Fausch et al. 2001; Copp et al. 2004; Vila-Gispert et al. 2005; Copp and Fox 2007; Ribeiro et al. 2008). One of the most successful fish introductions to Europe has been that of the North American centrarchid, pumpkinseed Lepomis gibbosus (L.). Introduced to European inland waters during the late nineteenth century, the pumpkinseed is now established in at least 28 countries of Europe and western Asia Minor (Copp and Fox 2007). Apart from recent studies of pumpkinseed populations in England (Copp et al. 2002; Villeneuve et al. 2005), all previous studies of pumpkinseed growth and lifehistory under natural thermal conditions have been undertaken in southern and central Europe (Copp et al. 2004; Fox et al. 2007). However, the increased attention to northwestern populations has revealed pumpkinseed to be more widely distributed within countries of northwestern Europe than was previously believed (e.g. Verreycken et al. 2007; Van Kleef et al. 2008), despite the fact that the pumpkinseed is considered a warmwater species. The study of northwestern European populations is especially relevant for understanding how pumpkinseed lifehistory varies according to local climate across a latitudinal cline, resulting in a different invasive potential. Moreover, using the relationship between age at maturity and juvenile growth, the potential invasiveness of pumpkinseed populations can be evaluated (Copp and Fox 2007).

The aim of the present study was to examine the variability of life-history traits of pumpkinseed 
populations across a latitudinal cline spanning northwestern Europe (southern Norway, northern and southern Netherlands, England, Belgium, northern France) in order to assess the potential invasiveness of the species in northwestern European and compare it with all available European populations (data compiled by Copp and Fox 2007). The specific objectives were to: (1) determine the general biological parameters and test for latitudinal clines in lifehistory traits of pumpkinseed within northwestern Europe, (2) test for the consistency of latitudinal clines in life history traits of pumpkinseed throughout Europe, and (3) examine the data in light of the model proposed by Copp and Fox (2007) to assess potential invasiveness of northwestern European pumpkinseed populations within a wider European context. Water temperature strongly influences the life-history traits of ectotherms in general (e.g. Atkinson 1994) and of pumpkinseed in particular (Fox and Crivelli 2001; Copp and Fox 2007), and is also negatively correlated with latitude. Consequently, we predicted that northwestern pumpkinseed populations would exhibit decreasing growth rates, increased age at maturity and reduced reproductive investment with increasing latitude and, thus, exhibit a lower invasiveness potential than southern Europe populations where potentially invasive populations have been reported (Fox et al. 2007).

\section{Methods}

Pumpkinseed were collected from 10 locations spanning northwestern Europe (Fig. 1; Table 1). Einedammen Pond (NEP), a 0.92 ha pond (mean depth $=1.5 \mathrm{~m}$ ) located outside of Oslo (Norway), contains the most northerly pumpkinseed population of Europe (Sterud and Jørgensen 2006). In the Netherlands, pumpkinseed were sampled in the Schoapedobbe Pond (HSP; surface area $=0.5$ ha; mean depth $=1.2 \mathrm{~m}$ ) and in the Meeuwven Pond (HMP; surface area $=3$ ha; mean depth $=1.0 \mathrm{~m}$ ). The English sites were composed of two ponds and one stream section. Batts Bridge Stream (EBS) is a small tributary of the River Ouse (Sussex); it flows southward through a number of on-line ponds (Klaar et al. 2004; Villeneuve et al. 2005). Cottesmore School Pond (ECS) is a small man-made pond of

Fig. 1 Map of the locations in northwestern Europe where pumpkinseed (Lepomis gibbosus) populations were sampled in the summers of 2005 and 2006 (site codes in Table 1)

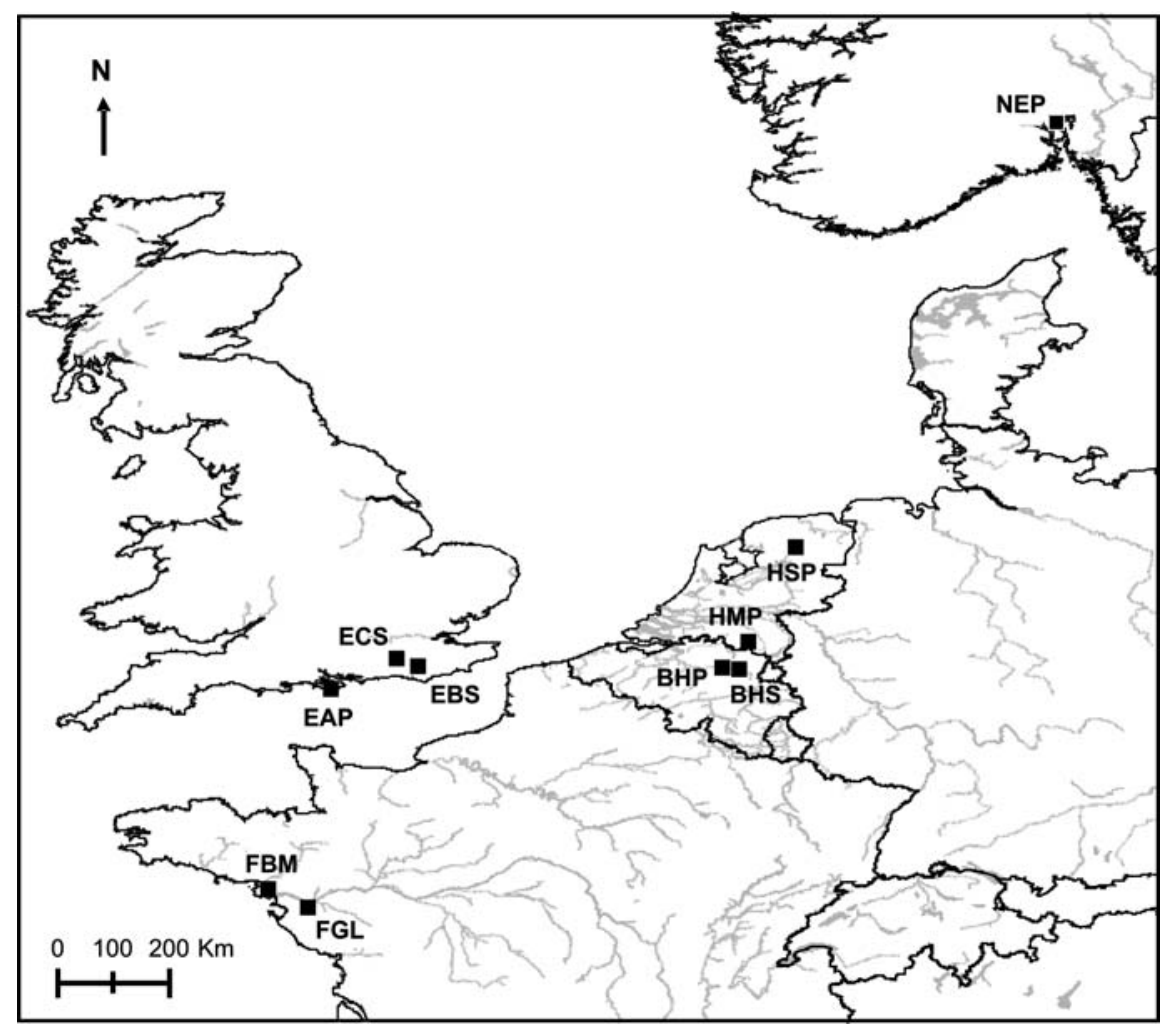


Table 1 Country, site code, site name, sampling dates, latitude and longitude of pumpkinseed Lepomis gibbosus populations sampling in northwestern Europe

\begin{tabular}{|c|c|c|c|c|c|}
\hline Country & Code & Site name & Sampling dates & Latitude & Longitude \\
\hline Norway & NEP & Einedammen Pond & 1 July 2006 & 59:49:00:N & 10:27:00:E \\
\hline \multirow[t]{2}{*}{ Holland } & HSP & Schoapedobbe Pond & 21 June 2006 & $52: 57: 07: \mathrm{N}$ & 06:15:30:E \\
\hline & HMP & Meeuwven Pond & 22 June 2006 & $51: 23: 28: \mathrm{N}$ & 05:29:59:E \\
\hline \multirow[t]{3}{*}{ England } & ECS & Cottesmore School Pond & 8 June 2006 & $51: 05: 14: \mathrm{N}$ & $00: 13: 15: \mathrm{W}$ \\
\hline & EBS & Batts Bridge Stream & 8 June 2006 & $51: 00: 47: \mathrm{N}$ & 00:04:27:W \\
\hline & EAP & Isle of Wight & 15 June 2005 & $50: 39: 11: \mathrm{N}$ & 01:11:03:W \\
\hline \multirow[t]{2}{*}{ Belgium } & BHP & Webbekomsbroek Pond & 23 June 2006 & $50: 58: 06: \mathrm{N}$ & 05:04:36:E \\
\hline & BHS & Slangebeek Stream & 23 June 2006 & $50: 57: 22: \mathrm{N}$ & 05:18:10:E \\
\hline \multirow[t]{2}{*}{ France } & FBM & Brière Marsh & 14-17 May 2006 & $47: 21: 58: \mathrm{N}$ & 02:18:45:W \\
\hline & FGL & Grand-Lieu Lake & 19 May 2006 & 47:05:00:N & 01:39:00:W \\
\hline
\end{tabular}

about 0.7 ha area and constitutes the upper-most water body of a small stream system (Copp et al. 2002). Airport Pond (EAP) is a small pond of about 0.72 ha area with a mean depth of $1.5 \mathrm{~m}$ located in the Isle of Wight (English Channel). Although Cottesmore and Airport ponds were originally artificial water bodies, they have undergone ecological succession over numerous decades to achieve a pseudo-natural character. In Belgium, the two sites were located in the northeast of the country. Slangebeek Stream (BHS) is a small tributary of the River Demer and the study stretch was approximately $2 \mathrm{~m}$ in width with a depth of $0.15-0.30 \mathrm{~m}$. Webbekomsbroek Pond (BHP) is an artificial water body of $\approx 2$ ha surface area (depth varying between 0.5 and $1 \mathrm{~m}$ ), with characteristics of near-natural floodplain ponds (Van Thuyne and Breine 2005). In France, the two sites belong to the River Loire drainage, in the northwest part of the country. Brière Marsh (FBM) is freshwater system $(9,000$ ha) composed of a complex network of permanently-flooded canals (Cucherousset et al. 2006). Grand-Lieu Lake (FGL) is a large, shallow, naturally turbid and eutrophic lake of 4,000 ha area (Paillisson and Marion 2006).

Pumpkinseed were collected in 2005 and 2006 during their spawning period (mainly from mid-May to early July) by various means (electrofishing: EBS, EAP, BHP, BHS, FBM, FGL; netting (because electrofishing was not possible): HSP, HMP; funnel trapping: ECS; angling (due to low water conductivity and dense ligneous debris): NEP; see Table 1 for site codes). Sample size at some sites was restricted due to low pumpkinseed density or reduced sampling efficiency (i.e. NEP and HSP). Captured fish were immediately killed by an overdose of anaesthetic and placed in a slurry of ice water and chilled to freezing.

After defrosting, each specimen was processed according to Fox (1994), which involved measurement for total length (TL, nearest $\mathrm{mm}$ ) and wet weight (nearest $0.1 \mathrm{~g}$ ), removal of the gonads by dissection for determination of weight (nearest $0.01 \mathrm{~g}$ ), sex and determination of maturity status. Female pumpkinseed with ovaries containing nonyolked or indistinguishable eggs were classed as immature, and those with ovaries containing yolked eggs were classed as mature. Scale samples were collected from between the lateral line and dorsal fin of each specimen. Importantly, when sample sizes for a given size-class were large, only a subset of the specimens were aged. Age was determined as per Steinmetz and Müller (1991) using scale impressions on acetate strips, read on a micro-projector (magnification: $47 \times$ ), with age determination cross-checked using independent readings by a second reader on a sub-sample of specimens. Back-calculation of TL at age was undertaken using the linear relationship between scale radius and TL (Creaser 1926). Backcalculated TL at age estimated from this formula employed a fixed body-scale intercept value of $24 \mathrm{~mm}$ so as to reduce bias due to differences in the size distribution used to generate the intercept (Fox and Crivelli 2001). To provide an estimator of juvenile growth rate, we calculated the mean TL at age 2, the earliest age at which female pumpkinseed mature in cool-water populations (Fox 1994). As an estimator of adult growth rate, annual length 
increment was calculated as the difference in TL between ages 2 and 3 , as TL at age 3 was the maximum age found in many of the sample sites.

Mean age at maturity $\left(A_{\mathrm{M}}\right)$ was calculated from the percentage of mature females in each age-class using the formula of DeMaster (1978) as adapted by Fox (1994):

$\alpha=\sum_{x=0}^{w}(x)[f(x)-f(x-1)]$

where $\alpha$ is the mean age at maturity, $x$ is the age in years, $f(x)$ is the proportion of fish mature at age $x$, and $\mathrm{w}$ is the maximum age in the sample. A modified version of this formula, using $10 \mathrm{~mm}$ TL intervals in place of age-classes (Trippel and Harvey 1987), was used to calculate mean total length at maturity $\left(\mathrm{TL}_{\mathrm{M}}\right)$ according to Fox and Crivelli (2001). Gonadosomatic index (GSI: $100 \times$ ovary weight $\div$ [total body weight - ovary weight]) was calculated for mature females only, as GSI is not a good indicator of reproductive allocation in male pumpkinseed (Danylchuk and Fox 1994). The sex-ratio was expressed as the number of males divided by the number of females.

As described by Ricker (1975, 1979), the linear relationship for TL versus weight was determined using all sampled individuals. Mean body condition factor was calculated according to Copp (2003) using the formula of Le Cren (1951), which requires populations to be sampled during the same period of the year: $K_{\mathrm{LC}}=w / w^{\prime}$, where $\mathrm{w}$ is the observed weight of each individual and $w^{\prime}$ is the expected weight using the length-weight relationship $\left(\log _{10} W=-a+b\right.$ $\log _{10} L$, where in this case $a=-5.382$ and $b=3.341$; $\left.r^{2}=0.9845, d f=847, P=0.0001\right) . K_{\mathrm{LC}}$ values $>1$ or $<1$ indicate that the individual is in better or worse condition, respectively, than the average individual of the same TL range. The slope parameter ' $b$ ' from the regression equation $\left(\log _{10} W=b\left(\log _{10} \mathrm{TL}\right) \pm a\right)$ was used as an estimator of 'generalised' condition (sensu Pitcher and Hart 1982).

Relationships between latitude and life-history traits (i.e., juvenile growth, adult growth, age at maturity, reproductive investment; proposed by Copp et al. 2002) and between age at maturity and juvenile growth were examined using linear regression, initially on the northwestern European data set and subsequently on the entire dataset available for
Europe (as compiled by Copp and Fox 2007). The relationship between age at maturity and juvenile growth is used as a means of assessing the potential invasiveness of pumpkinseed populations in Europe, whereby the transition phase between non-invasive and potentially invasive pumpkinseed populations is defined at its lower extent by the minimum age at maturity (age 1) and at its upper extent by the end of juvenile growth (which for many pumpkinseed populations is age 2, Fox 1994; Fox and Crivelli 2001; Copp et al. 2004). In this relationship, noninvasive populations of pumpkinseed, such as observed in England (Villeneuve et al. 2005), are characterised by slow juvenile growth (small at age 2) and late maturity. Whereas, potentially invasive pumpkinseed populations, such as reported for southern Europe (Fox et al. 2007), are characterised by fast juvenile growth (large at age 2) and early maturity. In the present study, we identified the position of each pumpkinseed population in northwestern European on the age at maturity versus juvenile growth rate axis, and evaluated whether each population was likely to be 'non-invasive', in the 'transitional' phase or 'potentially invasive' based on its position on the axis and the available knowledge on each population.

\section{Results}

Of 848 pumpkinseed examined for condition and reproduction traits, 653 were aged. Total length (TL) ranged from 18 to $158 \mathrm{~mm}(n=848)$, and maximum observed age was 4 years in six populations and 3 years in four populations (Table 2). Males outnumbered females in all populations, with sex ratio ranging from 1.1 to 3.2 (Table 2). TL at age 2 varied from 55 to $93 \mathrm{~mm}$, with mean annual growth increments for ages 1 to 2 varying from 19 to $55 \mathrm{~mm}$, and for ages 2 to 3 varying from 11 to $28 \mathrm{~mm}$. Mean body condition factor $\left(K_{\mathrm{LC}}\right)$ varied from 0.88 to 1.19 , and generalized condition $(b)$ varied from 2.47 to 3.64 (Table 2).

Age at maturity $\left(A_{\mathrm{M}}\right)$ and total length at maturity $\left(\mathrm{TL}_{\mathrm{M}}\right)$ could be estimated in eight of the ten populations of northwestern Europe (only mature fish were captured at NEP and only one immature fish (age 1,51 mm TL) was captured at HSP): $A_{\mathrm{M}}$ varied 
Table 2 For pumpkinseed populations in northwestern Europe, the site (see Table 1 for codes), total number of specimens $\left(n_{\mathrm{T}}\right)$, sex ratio (number of males $\div$ number females); number of specimens subjected to age analysis $\left(n_{\mathrm{A}}\right)$, the backcalculated TL at age $(\mathrm{mm})$ and annual length increments for ages 1-2 (L1-L2) and 2-3 (L2-L3), mean body condition factor $\left(K_{\mathrm{LC}}\right.$, Le Cren 1951), generalised condition ( $b$, slope of total length (TL) vs. weight relationship), mean age $\left(A_{\mathrm{M}}\right.$, in years) and total length $\left(\mathrm{TL}_{\mathrm{M}}\right.$, in $\left.\mathrm{mm}\right)$ at maturity, and mean gonado-somatic index (GSI, in \%)

\begin{tabular}{|c|c|c|c|c|c|c|c|c|c|c|c|c|c|c|c|}
\hline \multirow[t]{2}{*}{ Country } & \multirow[t]{2}{*}{ Site } & \multirow[t]{2}{*}{$n_{\mathrm{T}}$} & \multirow[t]{2}{*}{ Ratio } & \multicolumn{5}{|c|}{ Mean TL at age } & \multicolumn{2}{|c|}{ Increments } & \multicolumn{2}{|c|}{ Condition } & \multicolumn{3}{|c|}{ Reproduction } \\
\hline & & & & $n_{\mathrm{A}}$ & 1 & 2 & 3 & 4 & L1-L2 & L2-L3 & $K_{\mathrm{LC}}$ & $b$ & $A_{\mathrm{M}}$ & $\mathrm{TL}_{\mathrm{M}}$ & GSI \\
\hline Norway & NEP & 38 & 3.2 & 38 & 47 & 85 & 97 & - & 38 & 12 & 0.91 & 2.47 & $-\S$ & $-\S$ & 7.22 \\
\hline \multirow[t]{2}{*}{ Holland } & HSP & 54 & 1.3 & 53 & 38 & 93 & 113 & 124 & 55 & 20 & 1.00 & 3.05 & $-\S$ & $-\S$ & 10.04 \\
\hline & HMP & 100 & 1.5 & 100 & 36 & 55 & 66 & 70 & 19 & 11 & 0.91 & 2.80 & 2.00 & 60.0 & 8.78 \\
\hline \multirow[t]{3}{*}{ England } & ECS & 66 & 2.8 & 60 & 35 & 56 & 76 & 92 & 21 & 20 & 0.88 & 3.64 & 2.80 & 75.0 & 9.80 \\
\hline & EBS & 100 & 1.1 & 66 & 36 & 61 & 83 & - & 25 & 22 & 0.97 & 3.40 & 2.50 & 78.3 & 4.13 \\
\hline & EAP & 29 & 1.5 & 29 & 36 & 72 & 97 & 121 & 36 & 25 & 1.07 & 3.26 & 2.43 & 95.0 & 6.71 \\
\hline \multirow[t]{2}{*}{ Belgium } & BHP & 150 & 1.2 & 86 & 46 & 89 & 109 & 120 & 43 & 20 & 1.04 & 3.50 & 1.63 & 80.3 & 6.10 \\
\hline & BHS & 106 & 1.4 & 45 & 41 & 60 & 84 & - & 19 & 24 & 1.05 & 3.20 & 2.45 & 80.7 & 3.14 \\
\hline \multirow[t]{2}{*}{ France } & FBM & 105 & 1.7 & 102 & 46 & 83 & 111 & 131 & 37 & 28 & 1.04 & 3.33 & 1.00 & 65.0 & 11.20 \\
\hline & FGL & 100 & 2.0 & 74 & 40 & 73 & 95 & - & 33 & 22 & 1.19 & 3.31 & 1.71 & 63.0 & 11.36 \\
\hline
\end{tabular}

$\S$ Value not available due to missing age and size classes critical to calculation

Table 3 Statistics of the linear regressions $(y=b x+a)$ between latitude (lat) and juvenile growth rate (total length at age $\left.2 ; \mathrm{TL}_{\mathrm{L} 2}\right)$, adult growth increment $\left(\mathrm{TL}_{\mathrm{L} 2-3}\right)$, age at maturity
$\left(A_{\mathrm{M}}\right)$ and gonado-somatic index (GSI) and between juvenile growth rate and age at maturity of pumpkinseed in northwestern Europe and Europe

\begin{tabular}{|c|c|c|c|c|c|c|c|}
\hline Populations & $x$ & $y$ & $b$ & $a$ & $r^{2}$ & $d f$ & $P$-values \\
\hline \multirow[t]{5}{*}{ Northwestern Europe } & Lat & $\mathrm{TL}_{\mathrm{L} 2}$ & 0.928 & 25.530 & 0.051 & 8 & 0.529 \\
\hline & Lat & $\mathrm{TL}_{\mathrm{L} 2-3}$ & -1.044 & 73.897 & 0.461 & 8 & 0.031 \\
\hline & Lat & $A_{\mathrm{M}}$ & 0.237 & -9.781 & 0.495 & 6 & 0.051 \\
\hline & Lat & GSI & -0.238 & 20.055 & 0.084 & 8 & 0.418 \\
\hline & $\mathrm{TL}_{\mathrm{L} 2}$ & $A_{\mathrm{M}}$ & -0.035 & 4.466 & 0.561 & 6 & 0.033 \\
\hline \multirow[t]{5}{*}{ All Europe ${ }^{\dagger}$} & Lat & $\mathrm{TL}_{\mathrm{L} 2}$ & -1.232 & 129.758 & 0.205 & 41 & 0.001 \\
\hline & Lat & $\mathrm{TL}_{\mathrm{L} 2-3}$ & 0.026 & 17.447 & $<0.001$ & 41 & 0.905 \\
\hline & Lat & $A_{\mathrm{M}}$ & 0.091 & -2.052 & 0.299 & 31 & 0.002 \\
\hline & Lat & GSI & 0.008 & 7.164 & $<0.001$ & 34 & 0.927 \\
\hline & $\mathrm{TL}_{\mathrm{L} 2}$ & $A_{\mathrm{M}}$ & -0.036 & 4.798 & 0.571 & 31 & 0.001 \\
\hline
\end{tabular}

$\uparrow^{\dagger}$ The entire dataset available for Europe, i.e. those from Copp and Fox (2007) plus the present study

from 1.0 to 2.8 years and $\mathrm{TL}_{\mathrm{M}}$ varied from 60 to $95 \mathrm{~mm}$. Mean gonado-somatic index (GSI) was highly variable, ranging from 3.14 to $11.36 \%$ (Table 2). As expected, $A_{\mathrm{M}}$ decreased significantly with increasing juvenile growth rate (Table 3). Adult growth (TL increment between ages 2 and 3 ) decreased significantly with increasing latitude, and the increase in age at maturity with increasing latitude was very close to significant (Table 3). No significant variation with latitude was observed in the sex ratio $\left(r^{2}=0.25, P=0.14\right)$ nor in the juvenile growth and GSI of the pumpkinseed populations of northwestern Europe (Table 3).

When the northwestern European data were combined with those from elsewhere in Europe, no significant latitudinal cline was observed in adult growth increment or GSI, but $A_{\mathrm{M}}$ increased significantly with latitude and juvenile growth decreased with increasing latitude (Table 3 ). Using the relationship between age at maturity and juvenile growth derived for European pumpkinseed populations (Fig. 2; Table 3) as a predictor of potential 


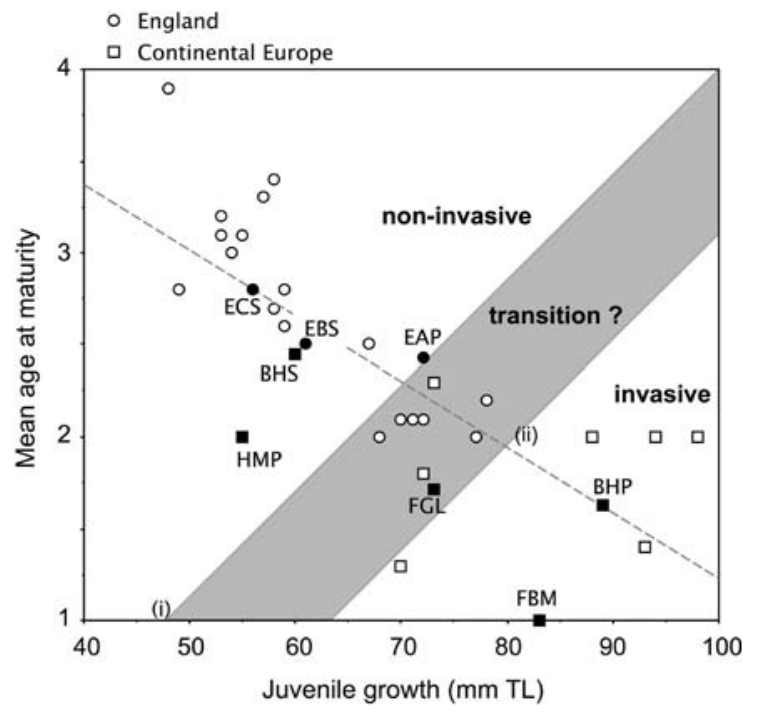

Fig. 2 Mean age at maturity ( $A_{\mathrm{M}}$, in years) as a function of mean juvenile growth (TL at age 2 ) for European pumpkinseed populations-redrawn from Copp and Fox (2007) with superimposed new data (from Table 2) indicated with filled squares and circles as well as the site code given in Table 1. The proposed physiological transition phase between noninvasive and potentially invasive pumpkinseed populations is hypothesized as extending from the minimum age at maturity (the $45^{\circ}$ line that traces from the intercept, at ' $i$ ') and the end of juvenile growth (which for many pumpkinseed populations is age 2 ; the $45^{\circ}$ line that traces through the age 2 intercept with the regression slope, at 'ii')

invasiveness, five of the study sites would be categorized as 'non-invasive' (ECS, EBS, BHS, HMP, EAP), one as 'transitional' (FGL) and two as 'potentially invasive' (BHP, FBM). The two sites for which age at maturity are missing (NEP, HSP) remain unclassified.

\section{Discussion}

Life-history traits, and in particular age at maturity and juvenile growth rate, have been advocated as a means of predicting the potential invasiveness of pumpkinseed in Europe (Copp and Fox 2007). As predicted, pumpkinseed populations in northwestern Europe exhibited slower growth with increasing latitude, though this was restricted to the age 2-3 growth interval. This is consistent with the pattern of faster centrarchid growth in warmer waters reported elsewhere (McCauley and Kilgour 1990; Fox and Crivelli 2001). However, juvenile growth was not related to latitude when only the northwestern
European populations were considered, whereas a significant relationship was established when the entire Europe level dataset was considered. This discrepancy might support the notion that environmental factors other than temperature become more important when considering a smaller latitudinal range.

The present study extends considerably the latitudinal range of current knowledge on the growth variability of introduced pumpkinseed, providing also information on sex ratio (not reported in previous studies). Sex ratio has been found to be a distinguishing, environmentally-linked character in another species invading northern Europe, the gibel carp Carassius gibelio (Vetemaa et al. 2005). However, in pumpkinseed, a species in which gynogenetic reproduction has not been reported, sex ratio did not vary with latitude in northwestern populations. As well, the present study provides information on pumpkinseed body condition, which has been reported elsewhere in Europe to vary greatly in pumpkinseed according to local conditions (Villeneuve et al. 2005), and this also appears to be the case in the northwestern parts of Europe (Table 2).

Assuming that latitude is an reasonable surrogate measure of general climatic conditions (water temperature and air temperature during the growing season), the results of the present and recent studies (Copp and Fox 2007) suggest that metabolism and growth performance changes with higher water temperature and longer growing seasons (e.g. higher food intake, higher food assimilation efficiency and/or lower energy expenditure; see also Dembski et al. 2006). Also as predicted, pumpkinseed populations in northwestern Europe exhibited a trend of later age at maturity than populations at lower latitude (Table 3), and this relationship was significant when all available data for Europe were included. The latitudinal clines in juvenile growth and age at maturity proposed previously (Copp et al. 2002; Villeneuve et al. 2005) were only partially corroborated in the present study, as juvenile growth was not related to latitude when only the northwestern European populations were considered, nor to gonado-somatic index with either population database. This suggests that age at maturity is a more useful (and reliable) means of assessing, even in smaller data sets such as this (Table 2), the reproductive response of pumpkinseed to environmental variability than other reproductive indices, 
such as GSI or length at maturity (Copp and Fox 2007). As such, age at maturity should be a good parameter for estimating the potential invasiveness of pumpkinseed by virtue of its rapid response to growth potential. Whereas, the lack of relationship between GSI and latitude is in contrast to the initial assessment for pumpkinseed in Europe (Copp et al. 2002). Also, one-off assessments of GSI can misrepresent the true allocation to reproduction (Copp and Fox 2007), since the species is known to spawn over shorter periods, and with fewer batches, in colder water (Fox and Crivelli 2001). Therefore, further investigation of reproductive investment, undertaken throughout the spawning season, is needed to better understand the influence of environmental factors on this life-history trait.

Despite its relatively specialized reproductive strategy (polyphilous nest-guarder, sensu Balon 1975), the pumpkinseed exhibits great plasticity, even 'opportunism' in its range of life-histories (Fox et al. 2007), tolerating a wide range of environmental conditions (Vila-Gispert et al. 2002). The ability to switch to a more opportunistic life-history strategy may facilitate the expansion of an invading species, even though the primary life-history strategy of the species is equilibrium (Fox et al. 2007). The parental care that is exhibited by the pumpkinseed and which is typical of many equilibrium strategists has been associated with successful invaders (e.g. Olden et al. 2006; Statzner et al. 2008), even though at least some of these invaders appear to adapt to the novel environment by putting more effort into reproduction (Fox et al. 2007).

Strong juvenile growth and precocious maturity, and thus shorter life-span, appear to be adaptive responses to elevated water temperatures, as is predicted for most ectotherms (Atkinson 1994). The distribution, age structure and invasiveness potential of pumpkinseed populations in Europe are expected to change under conditions of climate warming (Klaar et al. 2004; Villeneuve et al. 2005; Dembski et al. 2006). Indeed, fish life-history traits have been used as correlates of introduction success and extirpation events (review in Olden et al. 2006). Growth and maturation characteristics of a population are influenced by ambient environmental conditions (e.g. climate, food and habitat availability, absence/presence of predators and of other fish species-see Belk and Hales 1993; Fox 1994; Fox and Crivelli 2001;
Dembski et al. 2006). The model proposed by Copp and Fox (2007) is based on the relationship between juvenile growth and maturation, which is predicted for animals in general (Stearns 1992) and fish in particular (Fox 1994). It provides a useful means for assessing the potential invasiveness of pumpkinseed populations in Europe (Fig. 2). Indeed, almost all of the populations from southern Europe, where the species is considered invasive, exhibit fast juvenile growth and early maturity, i.e. the highest potential for population expansion by virtue of their short generation time (Copp and Fox 2007).

Within this context, two pumpkinseed populations located in the lower latitudes of the northwest Europe dataset (BHP, FBM) expressed $A_{\mathrm{M}}$ and juvenile growth characteristic of 'potentially invasive' populations (Fig. 2), and at both locations pumpkinseed were present in high densities. In contrast, the populations of two nearby sites (BHS, FGL) had $A_{\mathrm{M}}$ and juvenile growth values characteristic of noninvasive and transitional populations, respectively; and the densities of pumpkinseed at these sites were lower than the other nearby locations. In Belgium, this result may be due to the ecosystem characteristics (i.e. stream versus pond). Consistent with the original model (Copp and Fox 2007), the three studied English populations (ECS, EBS, EAP) fell into the non-invasive category, though the latter population borders the 'transition' zone (Fig. 2).

At present, neither of the most northerly populations (NEP, HSP) can be classified due to missing values and small sample sizes (see Table 2). Both of these populations were in very low abundance and shared their respective ponds with few or no other fish species at the time of sampling. The site near Oslo (NEP) is a recently introduced population (Sterud and Jørgensen 2006) and therefore may be at the start of an expansive establishment phase. And the site in northern Netherlands (HSP) had been subjected to an attempted eradication the year before sampling and therefore had been reduced by this human intervention to a status similar to that of the Norwegian population.

In conclusion, the use of the model proposed by Copp and Fox (2007), based on the relationship between juvenile growth and age at maturity, appeared to predict reasonably the status of pumpkinseed in Europe. However, other life-history characteristics (e.g. mortality rate, plasticity, reproductive 
strategy) are also likely to affect invasiveness (Olden et al. 2006; Statzner et al. 2008) and the model presented here undoubtedly does not capture all of the important biotic factors relating to invasive potential. As well, the alteration of the environment by human activities might increase species invasiveness (Vila-Gispert et al. 2005; Olden et al. 2006). Integrative tools are needed to predict species invasiveness (Kolar and Lodge 2001) and the applicability of this model to other species should be investigated. However, reliable growth and reproductive data for other species across their introduced range should be collected and the relationships between life-history traits and population invasiveness should be determined at the specific level.

Acknowledgments We thank the following persons for assisting in the collection and processing of pumpkinseed in Belgium (Y. Maes, I. Lambeens, M. De Wit, S. Buekenhout), England (J. Foster, D. Langley, D. Reeves), France (J.-M. Paillisson, A. Carpentier, J.-P. Damien), and Norway (A.T. Sterud, S.T. Sterud). Thanks also to D. Hogan for assistance with the scale reading. This study, which evolved from work initiated as part of a N.A.T.O. Collaborative Linkage Grant, was supported by research contracts/grants to G.H. Copp (UK Defra), to M.G. Fox (National Science and Engineering Research Council of Canada) and to E. Záhorská (Slovak Scientific Grant Agency grant to V. Kováč, Projects No. 1/ $2341 / 05$ and $1 / 0226 / 08$ ). We are grateful to two anonymous referees for providing insightful comments into an earlier version of the manuscript.

Open Access This article is distributed under the terms of the Creative Commons Attribution Noncommercial License which permits any noncommercial use, distribution, and reproduction in any medium, provided the original author(s) and source are credited.

\section{References}

Atkinson D (1994) Temperature and organism size-a biological law for ectotherms. Adv Ecol Res 25:1-58

Balon EK (1975) Reproductive guilds of fishes: a proposal and definition. J Fish Res Board Can 32:821-864

Belk MC, Hales LS Jr (1993) Predation-induced differences in growth and reproduction of bluegills (Lepomis macrochirus). Copeia 1993:1034-1044

Blanck A, Lamouroux N (2007) Large-scale intraspecific variation in life-history traits of European freshwater fish. J Biogeogr 34:862-875

Copp GH (2003) Is fish condition correlated with water conductivity? J Fish Biol 63:263-266

Copp GH, Fox MG (2007) Growth and life history traits of introduced pumpkinseed (Lepomis gibbosus) in Europe, and the relevance to invasiveness potential. In: Gherardi F (ed) Freshwater bioinvaders: profiles, distribution, and threats. Springer, Berlin, pp 289-306

Copp GH, Fox MG, Kováč V (2002) Growth, morphology and life history traits of a coolwater European population of pumpkinseed Lepomis gibbosus. Arch Hydrobiol 155: 585-614

Copp GH, Fox MG, Przybylski M et al (2004) Life-time growth patterns of pumpkinseed Lepomis gibbosus introduced to Europe relative to native North American populations. Folia Zool 53:237-254

Copp GH, Bianco PG, Bogutskaya NG et al (2005) To be, or not to be, a non-native freshwater fish? J Appl Ichthyol 21:242-262

Creaser CW (1926) The structure and growth of scales of fishes in relation to the interpretation of their life history, with special reference to the sunfish Eupomotis gibbosus. Mus Zool Univ Mich Misc Publ 17:1-82

Cucherousset J, Paillisson JM, Carpentier A et al (2006) Habitat use of an artificial wetland by the invasive catfish Ameiurus melas. Ecol Freshwat Fish 15:589-596

Danylchuk A, Fox MG (1994) Age and size dependent variation in the seasonal timing and probability of reproduction among mature female pumpkinseed. Environ Biol Fish 39:119-127

DeMaster DP (1978) Calculation of the average age of sexual maturity in marine mammals. J Fish Res Board Can 35: 912-915

Dembski S, Masson G, Monnier D et al (2006) Consequences of elevated temperatures on life-history traits of an introduced fish, pumpkinseed Lepomis gibbosus. J Fish Biol 69:331-346

Fausch KD, Taniguchi Y, Nakano S et al (2001) Flood disturbance regimes influence rainbow trout invasion success among five Holarctic regions. Ecol Appl 11:1438-1455

Fox MG (1994) Growth, density, and interspecific influences on pumpkinseed sunfish life histories. Ecology 75:11571171

Fox MG, Crivelli AJ (2001) Life history traits of pumpkinseed (Lepomis gibbosus) populations introduced into warm thermal environments. Arch Hydrobiol 150:561-580

Fox MG, Vila-Gispert A, Copp GH (2007) Life history traits of introduced Iberian pumpkinseed (Lepomis gibbosus) relative to native populations: can differences explain colonization success? J Fish Biol 71(Suppl D):56-69

García-Berthou E (2007) The characteristics of invasive fish: what have we learned so far? J Fish Biol 71((Suppl D)): 33-55

García-Berthou E, Alcaraz C, Pou-Rovira Q et al (2005) Introduction pathways and establishments rates of invasive aquatic species in Europe. Can J Fish Aquat Sci 62: 453-463

Klaar M, Copp GH, Horsfield R (2004) Autumnal habitat use of non-native pumpkinseed Lepomis gibbosus and associations with native fish species in small English streams. Folia Zool 53:189-202

Kolar CS, Lodge DM (2001) Progress in invasion biology: predicting invaders. Trends Ecol Evol 16:199-204

Le Cren ED (1951) The length-weight relationship and seasonal cycle in gonad weight and condition in the perch (Perca fluviatilis). J Anim Ecol 20:201-219 
Marchetti MP, Moyle PB, Levine R (2004) Alien fishes in California watersheds: characteristics of successful and failed invaders. Ecol Appl 14:587-596

McCauley RW, Kilgour DM (1990) Effect of air temperature on growth of largemouth bass in North America. Trans Amer Fish Soc 119:276-281

Olden JD, Poff NL, Bestgen KR (2006) Life-history strategies predict fish invasions and extirpations in the Colorado River Basin. Ecol Monograph 76:25-40

Paillisson JM, Marion L (2006) Can small water level fluctuations affect the biomass of Nymphaea alba in large lakes? Aquat Bot 84:259-266

Pitcher TJ, Hart PJB (1982) Fisheries ecology. Chapman and Hall, London, p 414

Ribeiro F, Elvira B, Collares-Pereira MJ et al (2008) Lifehistory traits of non-native fishes in Iberian watersheds across several invasion stages: a first approach. Biol Invasions 10:89-102

Ricker WE (1975) Computation and interpretation of biological statistics of fish populations. Fish Res Board Can Bull 191

Ricker WE (1979) Growth rates and models. In: Hoar WS, Randall DJ, Brett JR (eds) Fish physiology. Academic Press, London, pp 678-738

Statzner B, Bonada N, Doledec S (2008) Biological attributes discriminating invasive from native European stream macroinvertebrates. Biol Invasions 10:517-530

Stearns CS (1992) The evolution of life histories. Oxford University Press, Oxford

Steinmetz B, Müller R (1991) An atlas of fish scales, and other body structures used for age determination: non-salmonid species found in European fresh waters. Samara Publishing, Cardigan, p 51

Sterud E, Jørgensen A (2006) Pumpkinseed Lepomis gibbosus (Linnaeus, 1758) (Centrarchidae) and associated parasites introduced to Norway. Aquat Invas 1:278-280
Trippel EA, Harvey HH (1987) Reproductive responses of five white sucker (Catostomus commersoni) populations in relation to lake acidity. Can J Fish Aquat Sci 44:10181023

van Kleef H, van der Velde G, Leuven RSEW et al (2008) Pumpkinseed sunfish (Lepomis gibbosus) invasions facilitated by introductions and nature management strongly reduce macroinvertebrate abundance in isolated water bodies. Biol Invasions 10:1481-1490

Van Thuyne G, Breine J (2005) Visbestandopnames op de hengelvijver van het Webbekomsbroek te Webbekom (Diest) (2004). Instituut voor Bosbouw en Wildbeheer, HoeilaartGroenendaal, Belgium (IBW.Wb.V.R.2005.130), 9 pp

Verreycken H, Anseeuw D, Van Thuyne G et al (2007) The non-indigenous freshwater fishes of Flanders (Belgium): review, status and trends over the last decade. J Fish Biol 71(Suppl D):160-172

Vetemaa M, Eschbaum R, Albert A et al (2005) Distribution, sex ratio and growth of Carassius gibelio (Bloch) in coastal waters of Estonia (eastern Baltic Sea). J Appl Ichthyol 21:287-291

Vila-Gispert A, Moreno-Amich R, García-Berthou E (2002) Gradients of life-history variation: an intercontinental comparison of fishes. Rev Fish Biol Fish 12:417-427

Vila-Gispert A, Alcaraz C, García-Berthou E (2005) Life-history of invasive fish in small Mediterranean streams. Biol Invasions 7:107-116

Villeneuve F, Copp GH, Fox MG et al (2005) Interpopulation variation in growth and life history traits of the introduced sunfish, pumpkinseed Lepomis gibbosus, in Southern England. J Appl Ichthyol 21:275-281

Vitousek PM, Mooney HA, Lubchenco J et al (1997) Human domination of Earth's ecosystems. Science 277:494-499 